\title{
Acanthamoeba infection in a patient with chronic graft-versus-host disease occurring during treatment with voriconazole
}

D.R. Kaul, L. Lowe, G.S. Visvesvara, S. Farmen, Y.A. Khaled, G.A. Yanik. Acanthamoeba infection in a patient with chronic graft-versus-host disease occurring during treatment with voriconazole.

Transpl Infect Dis 2008: 10: 437-441. All rights reserved

Abstract: We report a case of disseminated infection with Acanthamoeba in a patient with graft-versus-host disease after hematopoietic stem cell transplant (HSCT) for acute lymphocytic leukemia. The infection involved the brain, skin, and lungs and occurred despite treatment with voriconazole for mold prophylaxis, and did not respond to treatment with multiple other agents reported to have activity against Acanthamoeba. To our knowledge, infection with Acanthamoeba has been reported in 4 other patients after HSCTor bone marrow transplant, and our case is the first to be diagnosed antemortem.

\author{
D.R. Kaul ${ }^{1}$, L. Lowe ${ }^{2}$, G.S. Visvesvara ${ }^{3}$, \\ S. Farmen ${ }^{4}$, Y.A. Khaled ${ }^{5}$, G.A. Yanik ${ }^{5}$ \\ Departments of ${ }^{1}$ Internal Medicine, Division of Infectious \\ Diseases and ${ }^{2}$ Pathology and Dermatology, University of \\ Michigan Medical School, Ann Arbor, Michigan, USA, \\ ${ }^{3}$ Division of Parasitology, Centers for Disease Control and \\ Prevention, Atlanta, Georgia, USA, ${ }^{4}$ Department of Pathology \\ and ${ }^{5}$ Blood and Bone Marrow Transplant Program, University \\ of Michigan Medical School, Ann Arbor, Michigan, USA \\ Key words: Acanthamoeba; protozoa; graft-versus-host \\ disease; voriconazole \\ Correspondence to: \\ Daniel R. Kaul, Division of Infectious Diseases, University of \\ Michigan Medical Center, Ann Arbor, MI 48109-5378, USA \\ Tel: + 17349365205 \\ Fax: + 17349362737 \\ E-mail: kauld@umich.edu
}

Received 16 January 2008, revised 18 March, 21 April 2008, accepted for publication 28 April 2008

DOI: $10.1111 /$ j.1399-3062.2008.00335.x

Transpl Infect Dis 2008: 10: 437-441
Despite widespread dissemination in the environment, Acanthamoeba are a rare cause of human diseases. Amebic keratitis (AK), granulomatous amebic encephalitis (GAE) with or without dissemination, and skin lesions are the most commonly reported clinical patterns $(1,2)$. With the exception of AK, infection with Acanthamoeba has been reported primarily in immunosuppressed patients. Most reports have been in patients with acquired immunodeficiency syndrome (AIDS), and only 4 patients, all post mortem, with GAE with or without disseminated disease after bone marrow or hematopoietic stem cell transplant (HSCT) have been described (2-9).

While no standard treatment for infection with Acanthamoeba has been described, a variety of agents have activity in vitro, in animal models, or have shown success in case reports (10-16). Recently, a case report suggested clinical response to voriconazole and amphotericin B in a lung transplant patient with skin lesions, and in vitro activity of voriconazole against some species of Acanthamoeba has been described $(13,15)$. We report the first case of
Acanthamoeba infection in a peripheral blood stem cell transplant (PBSCT) recipient diagnosed ante-mortem. In this patient, probable GAE with confirmed skin and pulmonary lesions developed despite the long-term prophylactic use of voriconazole to prevent invasive fungal infection in the setting of chronic graft-versus-host disease (GVHD).

\section{Case report}

The patient was a 53-year-old man with a history of acute lymphocytic leukemia who received a matched unrelated donor for PBSCT 930 days before presentation. The patient's post-transplant course was complicated by extensive chronic GVHD of the skin, eyes, mouth, and liver. The patient's home regimen of immunosuppression included tacrolimus $0.5 \mathrm{mg}$ twice daily, mycophenolate mofetil 
$1 \mathrm{~g}$ twice daily, and methylprednisolone $20 \mathrm{mg}$ daily. As antimicrobial prophylaxis, the patient was taking voriconazole $200 \mathrm{mg}$ twice daily, acyclovir $400 \mathrm{mg}$ twice daily, penicillin V $500 \mathrm{mg}$ twice daily, and trimethoprim/ sulfamethoxazole (TMP/SMX) 1 double-strength tablet twice a day on 2 days a week.

The patient was admitted to the hospital with sepsis and had bacteremic Pseudomonas aeruginosa pneumonia requiring mechanical ventilation. Because the patient remained poorly responsive, computed tomography (CT) of the head was performed and revealed an area of hyperdensity in the left periventricular area suggestive of subacute hemorrhage. Magnetic resonance imaging confirmed this impression, and because of hemorrhage, no comment on enhancement could be made (Fig. 1).

The patient's mental status improved and 3 days later he was transferred out of the intensive care unit. He developed fewer than 10 papular and ulcerated skin lesions on his face, leg, and arms (Fig. 2); biopsy was performed. Hematoxylin and eosin staining revealed amebic trophozoites and cyst forms (Fig. 3). Immunohistochemistry staining confirmed infection with Acanthamoeba (not shown).

The patient was started on treatment with liposomal amphotericin B (Ambisome) $5 \mathrm{mg} / \mathrm{kg}$ daily in combination with TMP $/ \mathrm{SMX}$ ( $5 \mathrm{mg} / \mathrm{kg}$ of the trimethoprim component) every $8 \mathrm{~h}$. The patient received 3 weeks of treatment without significant change in the skin or central nervous system (CNS) lesions, although no new skin lesions were observed. Miltefosine $100 \mathrm{mg}$ daily was obtained with

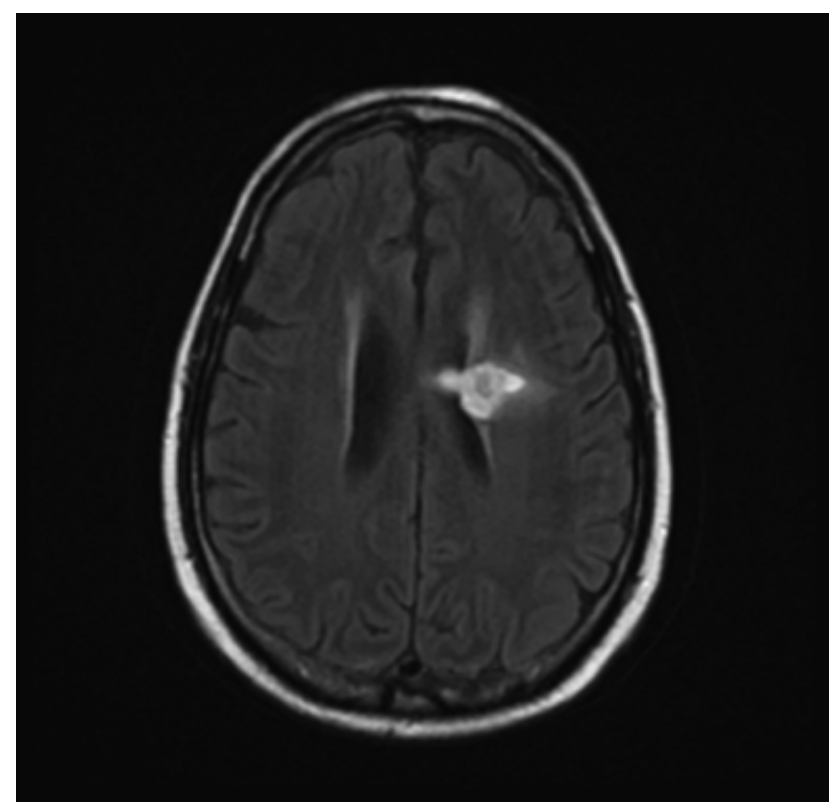

Fig. 1. Axial flair magnetic resonance imaging demonstrating $1.8 \mathrm{~cm} \times 1.9 \mathrm{~cm}$ area of hyperintensity in the left basal ganglia most consistent with parenchymal hemorrhage.

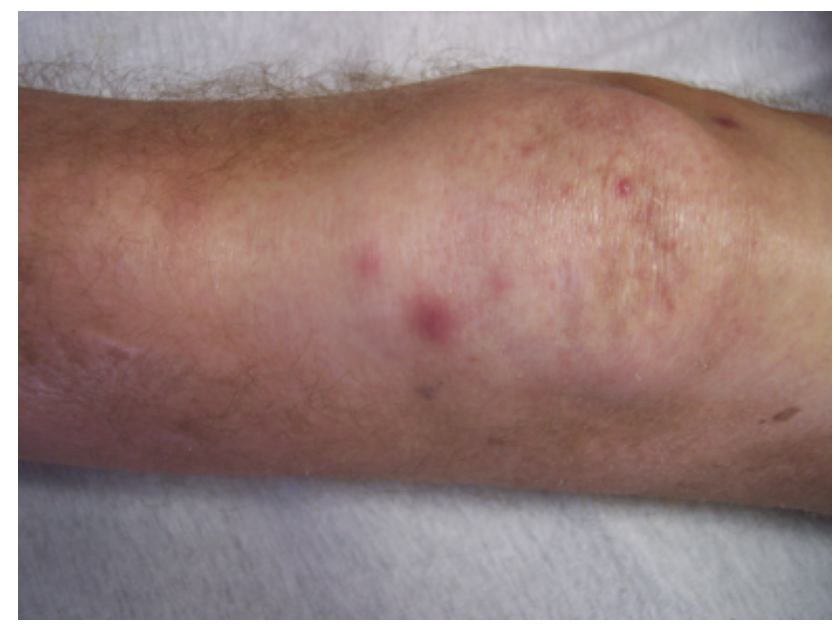

Fig. 2. Pustular lesions on left leg.

US Food and Drug Administration (FDA) approval for emergency use, and TMP/SMX and liposomal amphotericin were discontinued and voriconazole $300 \mathrm{mg}$ twice daily was restarted.

The patient developed worsening pulmonary status and patchy infiltrates on CT of the chest and was treated with ceftazadime $2 \mathrm{~g}$ every $8 \mathrm{~h}$, and amikacin $500 \mathrm{mg}$ inhaled twice a day. Over the next 2 weeks, the patient's condition deteriorated, and he developed mental status changes and increasing oxygen requirements. The patient died 5 weeks after the diagnosis of Acanthamoeba was originally made.

Autopsy was performed, and examination of the brain revealed hemorrhagic necrosis; the histology was consistent with GAE, but no organisms were identified in or near the hemorrhage (Fig. 4). In the lungs, areas of necrosis and consolidation were not visible grossly, but all random lung

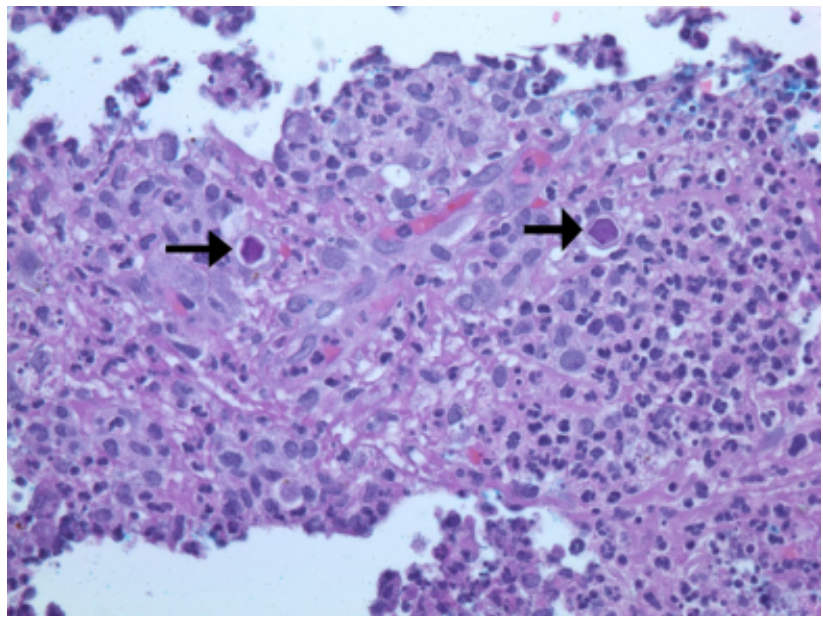

Fig. 3. Skin biopsy demonstrating cysts (arrows) within a suppurative tissue reaction (hematoxylin and eosin, $\times 400$ ). 


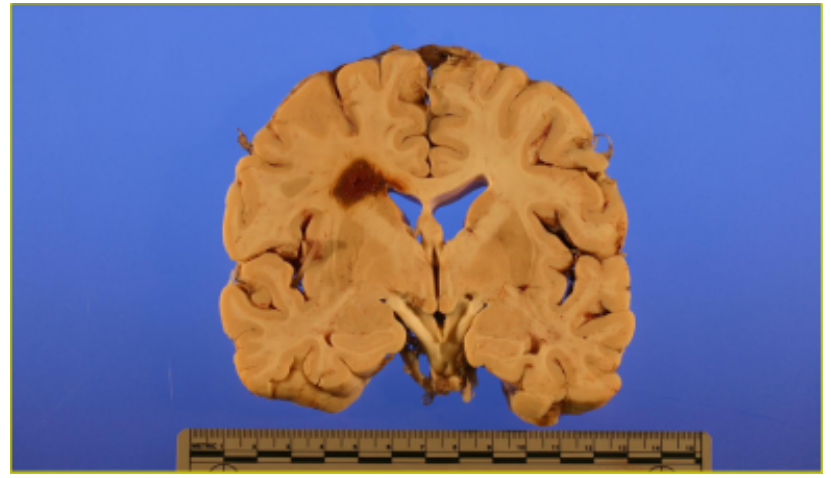

Fig. 4. Gross autopsy photo (brain) demonstrating a $1.9 \mathrm{~cm}$ hemorrhage with hemosiderin rim in the left frontal posterior periventricular white matter.

sections from both lungs contained Acanthamoeba cysts and trophozoites (Fig. 5).

\section{Discussion}

Infection secondary to Acanthamoeba is rare and very difficult to diagnose, and we present to our knowledge the first case diagnosed ante-mortem in a PBSCT or bone marrow transplant recipient. Diagnosis is generally made by observing trophozoites or cysts on tissue specimens. Particularly in patients with hematological malignancies, thrombocytopenia or poor overall condition, the opportunity to obtain a brain biopsy may be limited. Moreover, even if a biopsy is obtained, sampling area or failure to recognize the pathogen may limit diagnostic yield (17). In our case,

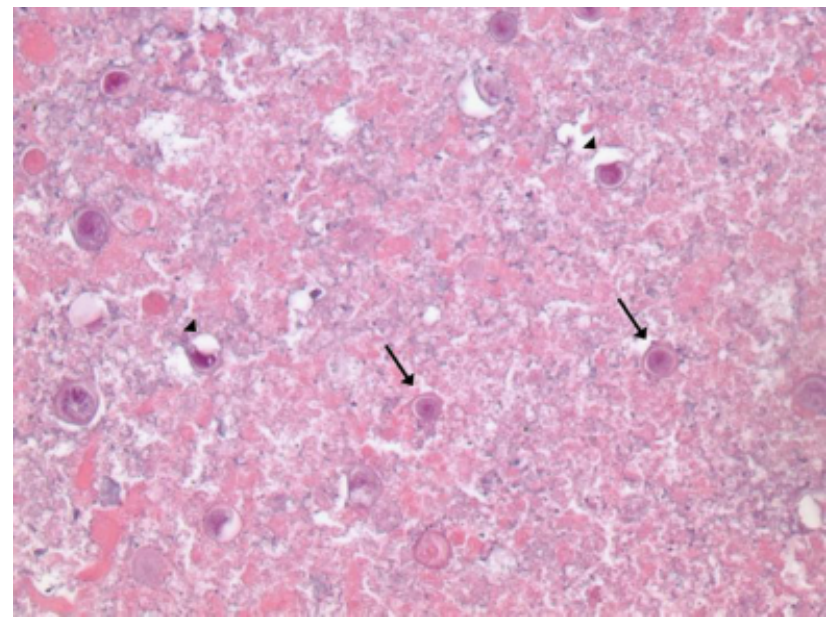

Fig. 5. Section of lung demonstrating numerous Acanthamoeba cysts and trophozoites (magnification $\times 40$ ). Arrows indicate trophozoites. Arrowheads indicate cysts. diagnosis was only made possible by the presence of skin lesions that could be easily biopsied with little risk to the patient.

Acanthamoeba are free-living ameba widely distributed in the environment. They have been isolated in soil and virtually any water source (e.g., tap or bottled water, contact lens solutions) (2). Thus, in most cases not involving contact lens solution, no specific exposure is identified. The most common clinical disease caused by Acanthamoeba is AK, which is related to contact lens use and generally occurs in immunocompetent individuals (2). CNS involvement, in contrast, usually occurs in immunosuppressed individuals, and typically presents as a subacute meningoencephalitis with ring enhancing or hemorrhagic lesions. Skin lesions with or without CNS lesions have also been described $(2,15)$. Lung involvement, as occurred in our patient, has been described in patients with $\operatorname{GAE}(2,3)$. While GAE was not proven by biopsy or autopsy in our case, a subacute CNS hemorrhage in an unusual location in the context of heavy immunosuppression, and cutaneously disseminated Acanthamoeba is suggestive of GAE.

Although AIDS is the most commonly reported risk factor for non-ocular Acanthamoeba, other risk factors include solid organ transplantation, connective tissue disease, diabetes, cirrhosis, renal failure, malignancies, and tuberculosis $(1,2,18-21)$. CNS or disseminated disease may occur in immunocompetent patients, but is rare. Three other reports describe 4 patients with disease caused by Acanthamoeba after HSCT or bone marrow transplant (Table 1) $(3,4,9)$. Interestingly, 3 of the 5 patients (including this report) had proven Acanthamoeba pneumonia at autopsy, and nodular infiltrates were noted weeks before the development of mental status changes. The range of time from first likely clinical manifestation to death was $11-82$ days. In all cases except ours, diagnosis was made on post-mortem examination, so no comments regarding the efficacy of treatment can be made.

An instructive aspect of our case is the occurrence of Acanthamoeba infection in a patient with GVHD treated with long-term voriconazole as prophylaxis $(200 \mathrm{mg}$ twice a day) against invasive fungal infection. The antifungal activity of voriconazole is based on inhibition of synthesis of ergosterol, which is also present in the plasma membrane of Acanthamoeba, providing a theoretical rationale for the anti-amebic activity of voriconazole observed in vitro (13). In one study, the in vitro activity of voriconazole was observed in 3 species of Acanthamoeba representative of the species most commonly found in clinical isolates (13). A case report demonstrated obvious improvement in cutaneous lesions in a lung transplant patient with skin disease treated with the combination of lipid amphotericin B and voriconazole (15). Our case, however, suggests that voriconazole may not always be effective. This may be sec- 
Hematopoietic stem cell transplant/bone marrow patients with Acanthamoeba infection

\begin{tabular}{|c|c|c|c|c|}
\hline Case (reference) & $\begin{array}{l}\text { Transplant/ } \\
\text { immunosuppression }\end{array}$ & $\begin{array}{l}\text { Clinical } \\
\text { presentation }\end{array}$ & Autopsy findings & $\begin{array}{l}\text { Tıme course (day } \\
\text { after transplant) }\end{array}$ \\
\hline $\begin{array}{l}39 \text { y.o. female } \\
\text { with CML and } \\
\text { dermatomyositis (3) }\end{array}$ & $\begin{array}{l}\text { Autologous } \\
\text { Recurrent disease and } \\
\text { myositis treated with } \\
\text { steroids, hyroxyurea, } \\
\text { hydroxychloroquine }\end{array}$ & $\begin{array}{l}\text { Progressive nodular } \\
\text { pulmonary infiltrates } \\
\text { Later neurologically } \\
\text { unresponsive }\end{array}$ & $\begin{array}{l}\text { Necrotizing } \\
\text { meningoencephalitis with } \\
\text { Acanthamoeba } \\
\text { Amebic pneumonitis } \\
\text { Adrenalitis }\end{array}$ & $\begin{array}{l}\text { First day of symptoms } \\
\text { day } 261 \\
\text { Died day } 286\end{array}$ \\
\hline $\begin{array}{l}32 \text { y.o. female with } \\
\text { AML (3) }\end{array}$ & $\begin{array}{l}\text { T cell-depleted marrow from } \\
\text { matched unrelated donor } \\
\text { Acute GVHD of the gut } \\
\text { treated with steroids }\end{array}$ & $\begin{array}{l}\text { Painful s.q. nodules } \\
\text { Conjunctivitis } \\
\text { Pulmonary nodules } \\
\text { Late mental status } \\
\text { changes }\end{array}$ & $\begin{array}{l}\text { Necrotizing } \\
\text { meningoencephalitis with } \\
\text { Acanthamoeba } \\
\text { Skin Acanthamoeba } \\
\text { Necrotizing Aspergillus } \\
\text { pneumonia }\end{array}$ & $\begin{array}{l}\text { First day of symptoms } \\
\text { day } 163 \\
\text { Died day } 181\end{array}$ \\
\hline $\begin{array}{l}47 \text { y.o. female } \\
\text { moncytoid B cell } \\
\text { lymphoma (4) }\end{array}$ & Autologous & $\begin{array}{l}\text { Right leg weakness and } \\
\text { urinary retention } \\
\text { Progressive mental status } \\
\text { changes }\end{array}$ & $\begin{array}{l}\text { Necrotic lesions with } \\
\text { Acanthamoeba in brain and } \\
\text { spinal cord }\end{array}$ & $\begin{array}{l}\text { First day of symptoms } \\
\text { day } 69 \\
\text { Died day } 80\end{array}$ \\
\hline $\begin{array}{l}45 \text { y.o. man } \\
\text { relapsed } \\
\text { AML }(9)\end{array}$ & $\begin{array}{l}\text { Partially mismatched related } \\
\text { donor } \\
\text { Thymoglobulin pre-transplant }\end{array}$ & $\begin{array}{l}\text { Cough with small nodules } \\
\text { on chest } \mathrm{CT} \text {, sinusitis } \\
\text { Later mental status } \\
\text { changes }\end{array}$ & $\begin{array}{l}\text { Amebic necrotizing } \\
\text { encephalitis } \\
\text { Necrotizing amebic } \\
\text { pneumonia }\end{array}$ & $\begin{array}{l}\text { First day of symptoms } \\
\text { day } 68 \\
\text { Died day } 150\end{array}$ \\
\hline $\begin{array}{l}53 \text { y.o. man with ALL } \\
\text { (current report) }\end{array}$ & $\begin{array}{l}\text { Matched unrelated donor } \\
\text { Extensive chronic } \\
\text { GVHD treated with } \\
\text { tacrolimus, mycophenalate } \\
\text { mofetil, methylprednisolone }\end{array}$ & $\begin{array}{l}\text { Admit with bacteremic } \\
\text { pneumonia } \\
\text { Developed skin lesions, } \\
\text { progressive } \\
\text { pulmonary lesions and GAE }\end{array}$ & $\begin{array}{l}\text { Skin and lungs with } \\
\text { Acanthamoeba } \\
\text { Necrosis and hemorrhage } \\
\text { in brain; no organisms seen }\end{array}$ & $\begin{array}{l}\text { First day of symptoms } \\
\text { day } 930 \\
\text { Died day } 965\end{array}$ \\
\hline
\end{tabular}

Table 1

ondary to poor absorption of the drug, inadequate dose, the overall state of immunosuppression of the patient, or poor activity against the particular species of Acanthamoeba infecting our patient. Miltefosine (hexadecylphosphocholine) is an anti-neoplastic agent that has been used to treat visceral leishmaniasis, and has in vitro activity against Acanthamoeba species, and clinical success has been described in a single case report $(13,16)$. The drug is not FDA-approved for use for any indication in the United States, but may be obtained for emergency use through the FDA. As Acanthamoeba cannot be grown in culture in clinical microbiology labs, susceptibility testing is generally not available.

\section{Conclusion}

We describe the first case, to our knowledge, of infection with Acanthamoeba diagnosed ante-mortem in an HSCT recipient. A high index of suspicion is necessary to make this diagnosis. Disease developed despite long-term prophylactic administration of voriconazole, and the patient did not respond to combination therapy with multiple agents reported to have activity against Acanthamoeba in vitro, in animal models, or in clinical case reports.

\section{References}

1. Cha JH, Furie K, Kay J,Walensky RP, Mullins ME, Hedley-Whyte ET. Case records of the Massachusetts General Hospital. Case 39-2006. A 24-year-old woman with systemic lupus erythematosus, seizures, and right arm weakness. N Engl J Med 2006; 355: 2678-2689.

2. Marciano-Cabral F, Cabral G. Acanthamoeba spp. as agents of disease in humans. Clin Microbiol Rev 2003; 16: 273-307.

3. Anderlini P, Przepiorka D, Luna M, et al. Acanthamoeba meningoencephalitis after bone marrow transplantation. Bone Marrow Transplant 1994; 14: 459-461.

4. Feingold JM, Abraham J, Bilgrami S, et al. Acanthamoeba meningoencephalitis following autologous peripheral stem cell transplantation. Bone Marrow Transplant 1998; 22: 297-300.

5. Gardner HA, Martinez AJ,Visvesvara GS, Sotrel A. Granulomatous amebic encephalitis in an AIDS patient. Neurology 1991; 41: 1993-1995. 
6. Gordon SM, Steinberg JP, DuPuis MH, Kozarsky PE, Nickerson JF, Visvesvara GS. Culture isolation of Acanthamoeba species and leptomyxid amebas from patients with amebic meningoencephalitis, including two patients with AIDS. Clin Infect Dis 1992; 15: 1024-1030.

7. Murakawa GJ, McCalmont T, Altman J, et al. Disseminated acanthamebiasis in patients with AIDS. A report of five cases and a review of the literature. Arch Dermatol 1995; 131: 1291-1296.

8. Seijo Martinez M, Gonzalez-Mediero G, Santiago P, et al. Granulomatous amebic encephalitis in a patient with AIDS: isolation of Acanthamoeba sp. Group II from brain tissue and successful treatment with sulfadiazine and fluconazole. J Clin Microbiol 2000; 38: 3892-3895.

9. Castellano-Sanchez A, Popp AC, Nolte FS, et al. Acanthamoeba castellani encephalitis following partially mismatched related donor peripheral stem cell transplantation. Transpl Infect Dis 2003; 5: 191-194.

10. Hunt SJ, Reed SL, Mathews WC, Torian B. Cutaneous Acanthamoeba infection in the acquired immunodeficiency syndrome: response to multidrug therapy. Cutis 1995; 56: 285-287.

11. Nachega JB, Rombaux P, Weynand B,Thomas G, Zech F. Successful treatment of Acanthamoeba rhinosinusitis in a patient with AIDS. AIDS Patient Care STDS 2005; 19: 621-625.

12. Oliva S, Jantz M, Tiernan R, Cook DL, Judson MA. Successful treatment of widely disseminated acanthamoebiasis. South Med J 1999; 92: 55-57.

13. Schuster FL, Guglielmo BJ, Visvesvara GS. In-vitro activity of miltefosine and voriconazole on clinical isolates of free-living amebas:
Balamuthia mandrillaris, Acanthamoeba spp., and Naegleria fowleri. J Eukaryot Microbiol 2006; 53: 121-126.

14. Sison JP, Kemper CA, Loveless M, McShane D, Visvesvara GS, Deresinski SC. Disseminated acanthamoeba infection in patients with AIDS: case reports and review. Clin Infect Dis 1995; 20: 1207-1216.

15. Walia R, Montoya JG, Visvesvera GS, Booton GC, Doyle RL. A case of successful treatment of cutaneous Acanthamoeba infection in a lung transplant recipient. Transpl Infect Dis 2007; 9: 51-54.

16. WalochnikJ, Aichelburg A, Assadian O, et al. Granulomatous amoebic encephalitis caused by Acanthamoeba amoebae of genotype $t 2$ in a human immunodeficiency virus-negative patient. J Clin Microbiol 2008; 46: 338-340.

17. Bloch KC, Schuster FL. Inability to make a premortem diagnosis of Acanthamoeba species infection in a patient with fatal granulomatous amebic encephalitis. J Clin Microbiol 2005; 43: 3003-3006.

18. Harwood CR, Rich GE, McAleer R, Cherian G. Isolation of Acanthamoeba from a cerebral abscess. Med J Aust 1988; 148: 47-49.

19. Calore EE, Cavaliere MJ, Calore NM. Cerebral amebiasis in the acquired immunodeficiency syndrome. Acta Neurol Belg 1997; 97: 248-250.

20. Koide J, Okusawa E, Ito T, et al. Granulomatous amoebic encephalitis caused by Acanthamoeba in a patient with systemic lupus erythematosus. Clin Rheumatol 1998; 17: 329-332.

21. Carter WW, Gompf SG, Toney JF, Greene JN, Cutolo EP. Disseminated Acanthamoeba sinusitis in a patient with AIDS: a possible role for early antiretroviral therapy. AIDS Read 2004; 14: 41-49. 